\title{
PERSEPSI ATAS PROFESIONALISME DOSEN DAN SARANA BELAJAR TERHADAP PRESTASI MAHASISWA DALAM MATA KULIAH BAHASA INDONESIA
}

\author{
Yolanda \\ Program Studi Pendidikan Bahasa Indonesia \\ Fakultas Bahasa dan Seni Universitas Indraprasta PGRI \\ Jl. Nangka 58 Tanjung Barat, Jakarta Selatan, 12530 \\ yolamatondang199@gmail.com
}

\begin{abstract}
Abstrak
Tujuan penelitian ini untuk mengetahui pengaruh persepsi profesionalisme dosen dan sarana belajar terhadap prestasi mahasiswa dalam mata kuliah Bahasa Indonesia di Akademi Litigasi Republik Indonesia Jakarta. Peneliti menggunakan metode penelitian Explanatory Survey Method. Responden penelitian terdiri atas 100 mahasiswa D3 ALTRI Program Administrasi Peradilan, dipilih berdasarkan teknik sampel bertujuan (purposive sampling). Instrumen menggunakan angket untuk variabel persepsi atas profesionalisme dosen dan sarana belajar, sedangkan variabel prestasi mahasiswa dalam mata kuliah bahasa Indonesia menggunakan nilai jadi mahasiswa yang diperoleh dari kartu hasil studi (KHS) mahasiswa. Hasil penelitian menyimpulkan, pertama, secara bersama-sama persepsi atas profesionalisme dosen dan sarana belajar berpengaruh positif terhadap prestasi mahasiswa dalam mata kuliah bahasa Indonesia. Kedua, persepsi atas profesionalisme dosen berpengaruh secara signifikan terhadap prestasi mahasiswa dalam mata kuliah Bahasa Indonesia. Ketiga, persepsi atas sarana belajar tidak berpengaruh secara signifikan terhadap prestasi mahasiswa dalam mata kuliah bahasa Indonesia.
\end{abstract}

Kata Kunci: persepsi, profesionalisme, dosen, sarana belajar, prestasi mahasiswa.

\section{Perception On Professionalism Lecturer And Learning Support Student Achievement Against The Indonesian Courses}

\begin{abstract}
The purpose of this study to determine the effect the perception of the professionalism of lecturers and learning tool towards the achievement of students in the subject of litigation Indonesian Academy of the Republic of Indonesia, Jakarta. Researchers used survey research methods Explanatory Survey Method. The respondents consisted of 100 students of D3 ALTRI Administration of Justice Program, selected based on purposive sampling. The instrument uses a questionnaire to the variable perception of the professionalism of lecturer and learning facilities, while the variables of students achievement in the subject of Indonesian use so students value obtained from results of a study card students. The study concluded, first, jointly perception of the professionalism of lecturer and learning facilities positive effect on student achievement in the subject of Indonesian. Second, the perception of professionalism lecturers significantly affect student achievement in the subject of Indonesian. Third, the perception of a leraning tool does not significantly affect the student achievement in subjects Indonesian.
\end{abstract}

Keywords: perception, professionalism, lecturers, learning tools, student achievement 


\section{PENDAHULUAN}

\section{LATAR BELAKANG}

Hasil observasi sementara yang penulis lakukan di Akademi Litigasi Indonesia (ALTRI) Jakarta menunjukkan terdapat perbedaan prestasi belajar di antara mahasiswa. Menurut Dalyono (2001: 239) prestasi belajar dipengaruhi oleh dua faktor, yaitu faktor intern dan faktor ekstern. Faktor intern adalah faktor yang berasal dari dalam manusia yang terdiri atas faktor fisiologis dan faktor psikologis. Faktor ekstern adalah faktor yang berasal dari luar diri manusia yang terdiri atas lingkungan keluarga, lingkungan kampus, lingkungan masyarakat, dan media massa.

Dengan bertitik tolak dari permasalahan di atas, penulis memandang perlu untuk mengadakan suatu penelitian dengan judul "Hubungan Persepsi atas Profesionalisme Dosen dan Sarana Belajar terhadap Prestasi Mahasiswa dalam Mata Kuliah Bahasa Indonesia di Akademi Litigasi Indonesia Jakarta"

\section{TINJAUAN PUSTAKA}

Pengertian profesional menurut Arikunto (1993) yang mengutip dari Oxford Dictionary, menjelaskan bahwa di dalam suatu pekerjaan profesional diperlukan teknik serta prosedur yang bertumpu pada landasan intelektual yang dipelajari dari suatu lembaga (baik formal maupun tidak formal) kemudian diterapkan di masyarakat untuk pemecahan suatu masalah Menurut Mulyasa (2004), "Sarana pendidikan adalah peralatan dan perlengkapan yang secara langsung dipergunakan dan menunjang proses pendidikan, khususnya proses belajar, mengajar, seperti gedung, ruang kelas, meja kursi, serta alat-alat dan media pengajaran".

Kemudian, Hamalik (1990), mengartikan prestasi belajar adalah hasil belajar yang telah dicapai oleh peserta didik yang diwujudkan dengan nilai atau huruf dalam rapor peserta didik atau Kartu Hasil Studi (KHS) mahasiswa.

\section{METODE PENELITIAN}

Penelitian ini dilaksanakan di Akademi Litigasi Republik Indonesia Jakarta. Dalam penelitian ini yang menjadi populasi penelitian adalah seluruh mahasiswa program studi administrasi peradilan jenjang D3 di Akademi Litigasi Republik Indonesia Jakarta. Pengambilan sampel dalam penelitian ini dilakukan dengan metode nonprobability sampling. Metode nonprobability sampling adalah teknik pengambilan sampel yang tidak memberi peluang atau kesempatan sama bagi setiap unsur atau anggota populasi untuk dipilih menjadi sampel. Teknik penarikan sampel yang digunakan pada penelitian ini adalah sampel aksidental atau sampel cara dipermudah (convinience sampling), yaitu penarikan sampel berdasarkan pertimbangan atau kriteria tertentu. Dalam hal ini, sampel dipilih secara spontanitas atau sampel yang dianggap dapat mewakili populasi. Metode ini dilakukan dengan memilih 100 mahasiswa ALTRI Jakarta yang telah menempuh mata kuliah Bahasa Indonesia dan baru mengikuti mata kuliah tersebut. Sampel terdiri atas 33 orang mahasiswa kelas A, 34 orang mahasiswa kelas $\mathrm{B}$, dan 33 orang mahasiswa kelas $\mathrm{C}$ dengan program studi Administrasi Peradilan.

Metode pengumpulan data yang digunakan penulis dalam melaksanakan penelitian ini adalah studi pustaka, kuesioner. Setiap jawaban responden diberi skor dengan skala Likert berdimensi 5 skala dengan kategori (sesuai dengan tujuan pertanyaan/pernyataan). 


\section{HASIL DAN PEMBAHASAN}

Penelitian ini terdiri atas tiga variabel, yaitu variabel prestasi mahasiswa mata kuliah Bahasa Indonesia (Y) sebagai variabel terikat, variabel persepsi atas profesionalisme dosen $\left(\mathrm{X}_{1}\right)$, dan sarana belajar $\left(\mathrm{X}_{2}\right)$ sebagai variabel bebas.

Skor variabel Prestasi Mahasiswa dalam Mata Kuliah Bahasa Indonesia (Y)

Variabel Prestasi mahasiswa dalam mata kuliah Bahasa Indonesia dalam penelitian ini adalah skor atau nilai yang diperoleh mahasiswa dalam menjawab tes sejumlah pokok bahasan yang meliputi komponen pemahaman, kebahasaan, dan penggunaan Bahasa Indonesia dalam jangka waktu tertentu, sebagai indikasi mahasiswa telah menguasai materi pelajaran yang disampaikan.

Berdasarkan penelitian data untuk prestasi mahasiswa dalam mata kuliah
Bahasa Indonesia yang dikumpulkan dengan mempergunakan instrumen penelitian, untuk mengukur prestasi mahasiswa dalam mata kuliah bahasa Indonesia menggunakan nilai jadi mahasiswa yang diperoleh dari kartu hasil studi (KHS) mahasiswa.

Setelah dilakukan pengolahan terhadap data penelitian untuk skor prestasi belajar Bahasa Indonesia diperoleh skor tertinggi 95 dan skor terendah 40. Dengan demikian, rentang skor antara nilai tertinggi dan nilai terendah adalah 55. Berdasarkan nilai rentangan tersebut dapat ditentukan banyaknya kelas interval adalah 8 dan panjang kelas interval 7 yang selanjutnya digunakan untuk membuat distribusi frekuensi.

Dengan menggunakan aturan Sturgess, distribusi frekuensi skor Prestasi Mahasiswa dalam mata kuliah Bahasa Indonesia (Y) dapat dilihat pada tabel 4.1

Tabel 4.1

Distribusi Frekuensi Skor Prestasi Mahasiswa Dalam Mata Kuliah Bahasa Indonesia (Y)

\begin{tabular}{ccccc}
\hline No & Interval Kelas & Absolut & $\begin{array}{c}\text { Frekuensi } \\
\text { Relatif } \\
(\boldsymbol{\%})\end{array}$ & $\begin{array}{c}\text { Kumulatif } \\
(\boldsymbol{\%})\end{array}$ \\
1 & $40-46$ & 5 & 5 & 5 \\
2 & $47-53$ & 1 & 1 & 6 \\
3 & $54-60$ & 8 & 8 & 14 \\
4 & $61-67$ & 9 & 9 & 23 \\
5 & $68-74$ & 4 & 4 & 27 \\
6 & $75-81$ & 37 & 37 & 64 \\
7 & $82-88$ & 20 & 20 & 84 \\
8 & $89-95$ & 16 & 16 & 100 \\
& Jumlah & $\mathbf{1 0 0}$ & $\mathbf{1 0 0 \%}$ & \\
\hline
\end{tabular}




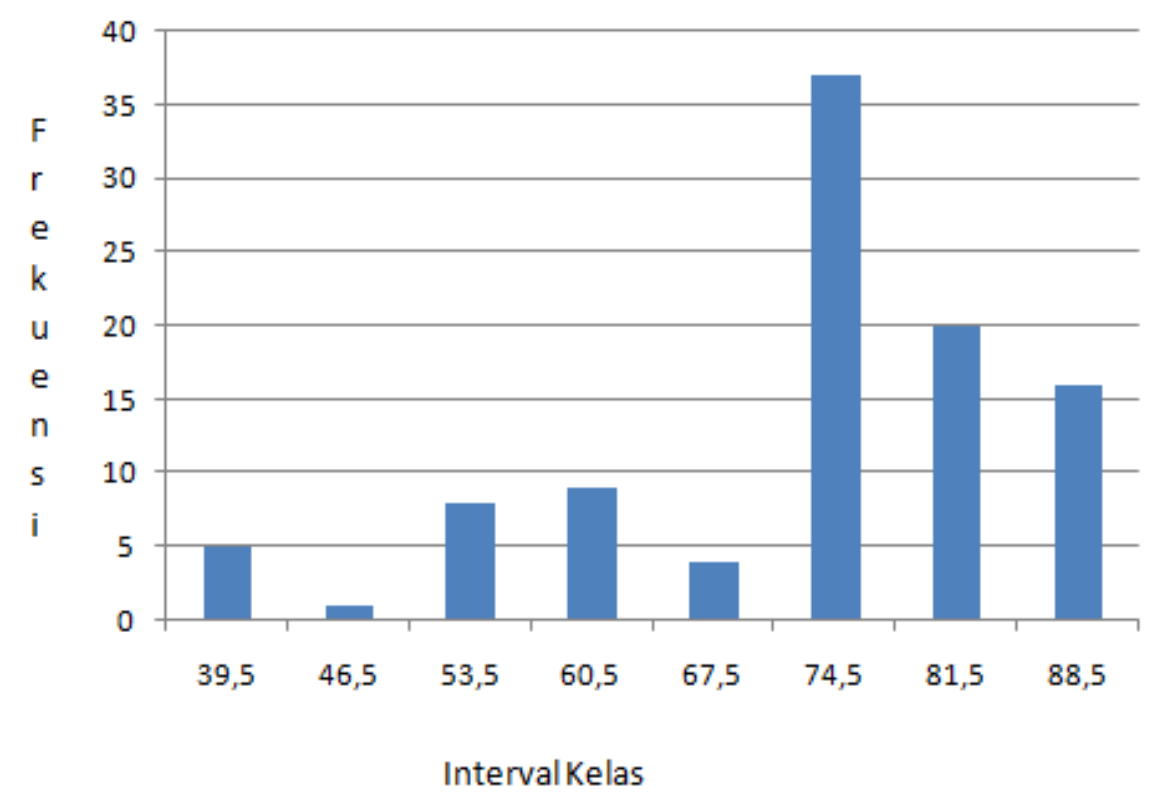

Gambar 4.1. Histogram Sebaran Data Prestasi Mahasiswa Mata Kuliah Bahasa Indonesia

Dari hasil analisis data untuk variabel prestasi mahasiswa dalam mata kuliah Bahasa Indonesia, keragaman datanya ditunjukkan dengan adanya nilai variansi sebesar 155,081 dan standar deviasinya sebesar 12,453. Data dari variabel itu mempunyai rerata 76,99 modus sebesar 80 dan median sebesar 80. Hal itu menunjukkan bahwa rata-rata skor prestasi mahasiswa dalam mata kuliah Bahasa Indonesia adalah cukup tinggi.

\section{Data Variabel Persepsi atas Profesionalisme Dosen $\left(\mathbf{X}_{1}\right)$}

Variabel persepsi atas profesionalisme dosen adalah skor persepsi mahasiswa terhadap profesionalisme dosen yang merupakan kondisi, arah, nilai, tujuan dan kualitas suatu keahlian dan kewenangan dalam bidang pendidikan dan pengajaran yang berkaitan dengan pekerjaan seseorang yang menjadi mata pencaharian.

Berdasarkan penelitian data untuk persepsi atas profesionalisme dosen yang dikumpulkan dengan mempergunakan instrumen penelitian, untuk mengukur persepsi atas profesionalisme dosen menggunakan 9 butir pertanyaan yang diajukan ke responden dengan skor tertinggi 45 dan skor terendah 10. Dengan demikian, diperoleh rentang teoritis untuk variabel persepsi atas profesionalisme dosen, yaitu sebanyak 9 butir yang disusun berdasarkan Skala Likert, dengan alternatif jawaban sebagai berikut: (1) sangat setuju, (2) setuju, (3) kadangkadang, (4) tidak setuju, (5) sangat tidak setuju.

Setelah dilakukan pengolahan data penelitian untuk skor persepsi atas profesionalisme dosen pada mahasiswa ALTRI Jakarta yang dikumpulkan dengan skala persepsi atas profesionalisme dosen, diperoleh skor tertinggi 45 dan skor terendah 10 . Dengan demikian, rentang skor antara nilai tertinggi dan nilai terendah adalah 35. Berdasarkan nilai rentangan tersebut, dapat ditentukan bahwa banyaknya kelas interval adalah 8 dan panjang interval adalah 5 yang selanjutnya digunakan untuk membuat daftar distribusi frekuensi. Dengan menggunakan aturan Sturges, distribusi frekuensi skor 
persepsi atas profesionalisme dosen $\left(\mathrm{X}_{1}\right)$

dapat dilihat pada Tabel 4.2.

Tabel 4.2

Distribusi Frekuensi Persepsi atas Profesionalisme Dosen $\left(\mathrm{X}_{1}\right)$

\begin{tabular}{|c|c|c|c|c|}
\hline \multirow{2}{*}{ No } & \multirow{2}{*}{$\begin{array}{c}\text { Interval } \\
\text { Kelas }\end{array}$} & Absolut & Relatif (\%) & $\begin{array}{c}\text { Kumulatif } \\
(\boldsymbol{\%})\end{array}$ \\
\cline { 3 - 5 } & $10-14$ & 1 & 1 & 1 \\
\hline 1 & $15-19$ & 0 & 0 & 1 \\
\hline 2 & $20-24$ & 3 & 3 & 4 \\
\hline 3 & $25-29$ & 10 & 10 & 14 \\
\hline 4 & $30-34$ & 29 & 29 & 43 \\
\hline 5 & $35-39$ & 48 & 48 & 91 \\
\hline 6 & $40-44$ & 8 & 8 & 99 \\
\hline 7 & $45-49$ & 1 & 1 & 100 \\
\hline 8 & 45 & $\mathbf{1 0 0}$ & $\mathbf{1 0 0 \%}$ & \\
\hline \multicolumn{2}{|c|}{ Jumlah } & & &
\end{tabular}

Kemudian dari tabel di atas dapat dibuatkan histogram data variabel persepsi atas profesionalisme dosen mahasiswa ALTRI di Jakarta yang berguna untuk melengkapi penyajian data seperti pada gambar berikut.

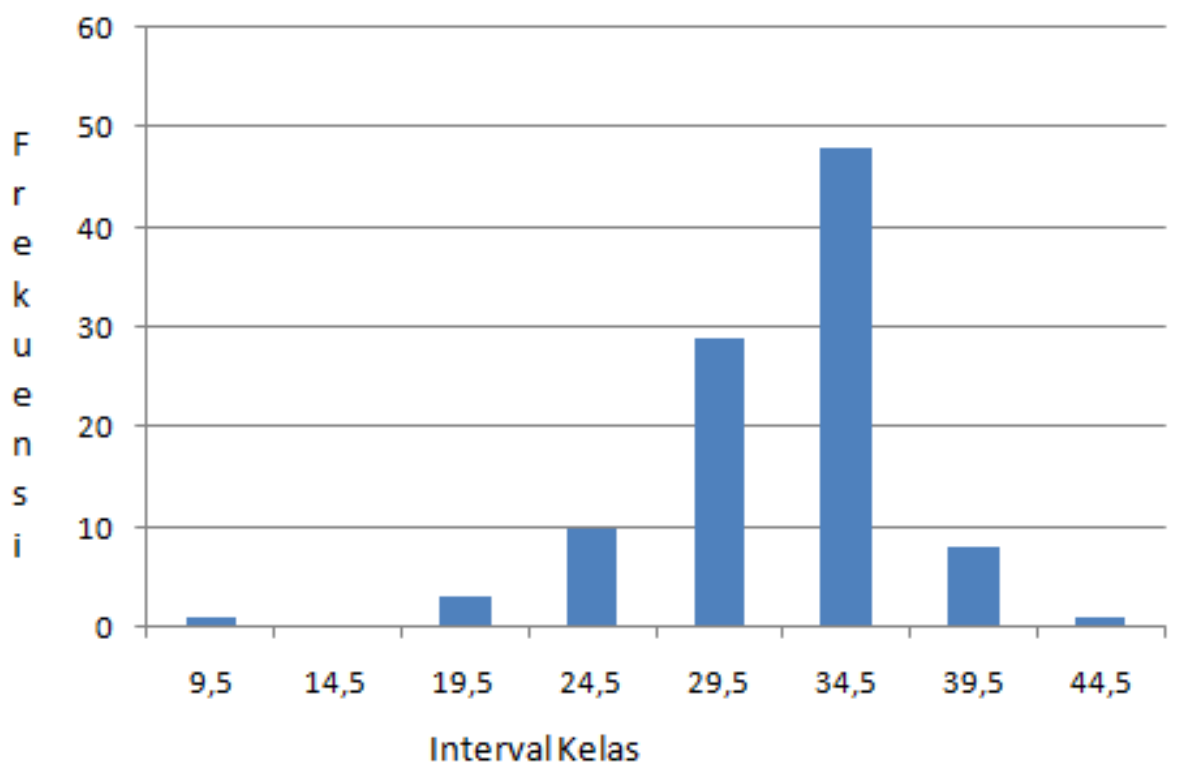

Gambar 4.2 Histogram Sebaran Data Persepsi atas Profesionalisme Dosen

Dari hasil analisis data untuk variabel persepsi atas profesionalisme dosen, keragaman datanya ditunjukkan dengan adanya nilai variansi sebesar 25,969 dan standar deviasinya 5,096. Data dari variabel ini mempunyai rerata 34,48; modus 36; dan median 36.
Data Variabel Sarana Belajar

Variabel sarana belajar dalam penelitian ini adalah skor sesuatu yang dapat digunakan dan dimanfaatkan dalam pelaksanaan kegiatan belajar mengajar. Sarana belajar dapat dibedakan menjadi dua kelompok, yaitu (a) peralatan yang merupakan sesuatu 
yang digunakan untuk pembelajaran dan (b) perlengkapan merupakan sesuatu yang melengkapi kebutuhan sarana. Berdasarkan penelitian data untuk sarana belajar yang dikumpulkan dengan mempergunakan instrumen penelitian, untuk mengukur sarana belajar menggunakan 9 butir pertanyaan yang diajukan ke responden dengan skor tertinggi 45 dan skor terendah 10. Dengan demikian diperoleh rentang teoritis untuk variabel sarana belajar 9 sampai 45. Rentang skor teoritis tersebut diperoleh dari jumlah butir yang terdapat dalam instrumen sarana belajar, yaitu sebanyak 9 butir yang disusun berdasarkan Skala Likert, dengan alternatif jawaban sebagai berikut: (1) sangat setuju, (2) setuju, (3) kadang- kadang, (4) tidak setuju, (5) sangat tidak setuju.

Setelah dilakukan pengolahan terhadap data penelitian untuk skor sarana belajar pada mahasiswa ALTRI Jakarta yang dikumpulkan dengan skala sarana belajar diperoleh skor tertinggi 45 dan skor terendah 10. Dengan demikian, rentang skor antara nilai tertinggi dan nilai terendah adalah 35 . Berdasarkan nilai rentangan tersebut dapat ditentukan banyaknya kelas interval adalah 8 dan panjang interval sebesar 5 yang selanjutnya digunakan untuk membuat daftar distribusi frekuensi.

Dengan menggunakan aturan Sturges, distribusi frekuensi skor sarana belajar $\left(\mathrm{X}_{2}\right)$ dapat dilihat pada Tabel berikut.

Tabel 4.3

Distribusi Frekuensi Sarana Belajar $\left(\mathrm{X}_{2}\right)$

\begin{tabular}{|c|c|c|c|c|}
\hline \multirow{2}{*}{ No } & \multirow{2}{*}{$\begin{array}{c}\text { Interval } \\
\text { Kelas }\end{array}$} & Absolut & Relatif (\%) & $\begin{array}{c}\text { Kumulatif } \\
(\boldsymbol{\%})\end{array}$ \\
\cline { 3 - 5 } & $10-14$ & 1 & 1 & 1 \\
\hline 1 & $15-19$ & 1 & 1 & 2 \\
\hline 2 & $20-24$ & 6 & 6 & 8 \\
\hline 3 & 14 & 14 & 22 \\
\hline 4 & $25-29$ & 29 & 29 & 51 \\
\hline 5 & $30-34$ & 34 & 34 & 85 \\
\hline 6 & $35-39$ & 12 & 12 & 97 \\
\hline 7 & $40-44$ & 3 & 3 & 100 \\
\hline 8 & $45-49$ & $\mathbf{1 0 0}$ & $\mathbf{1 0 0 \%}$ & \\
\hline \multicolumn{2}{|c|}{ Jumlah } & &
\end{tabular}

Kemudian, dari tabel di atas, dapat dibuatkan histogram data variabel sarana belajar mahasiswa ALTRI Jakarta yang berguna untuk melengkapi penyajian data seperti pada gambar berikut. 


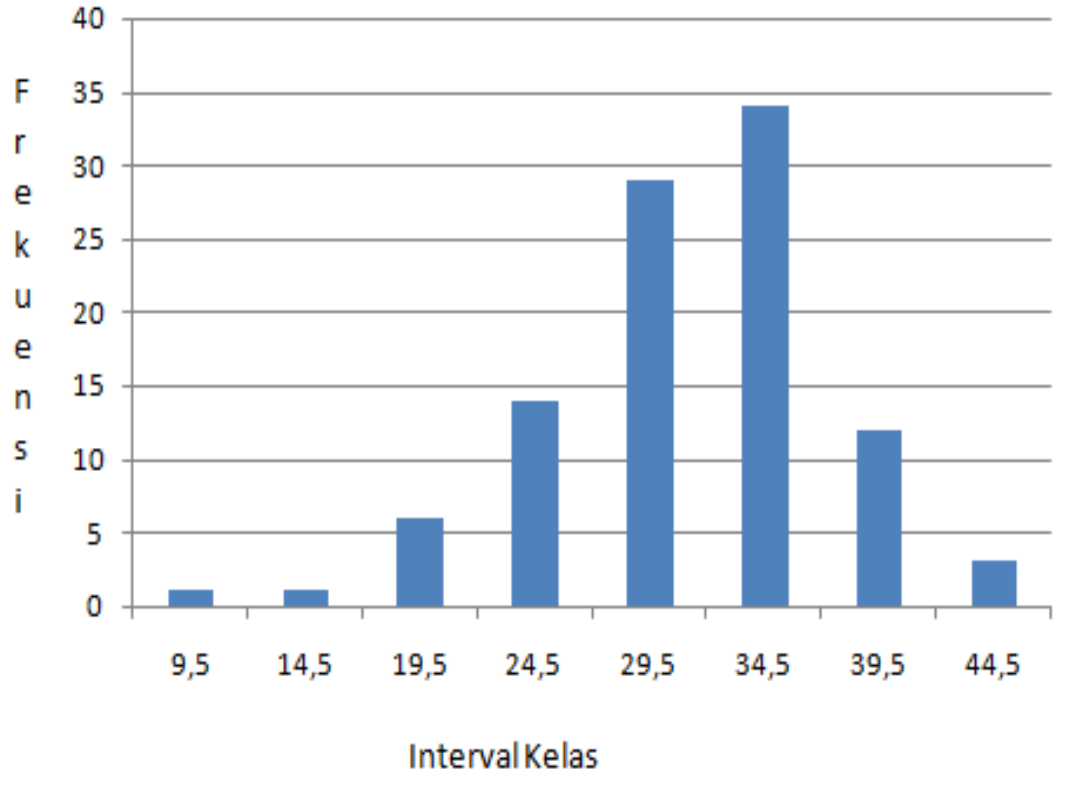

Gambar 4.3 Histogram Sebaran Data Sarana Belajar Mahasiswa ALTRI Jakarta

Dari hasil analisis data untuk variabel sarana belajar, keragaman datanya ditunjukkan dengan adanya nilai variansi 38,919 dan standar deviasinya 6,239. Data dari variabel ini mempunyai rerata sebesar 33,51; modus 36; dan median 34. Hal itu menunjukkan bahwa rata-rata skor sarana belajar cukup tinggi. Berikut disajikan secara lengkap hasil analisis deskriptif untuk ketiga variabel seperti pada Tabel 4.4 di bawah ini.

Tabel 4.4

Rangkuman Deskripsi Data Variabel X1,X2, dan Y

\begin{tabular}{|c|c|c|c|c|}
\hline \multicolumn{5}{|c|}{ Statistics } \\
\hline & & $\begin{array}{l}\text { PRESTASI } \\
\text { BELAJAR }\end{array}$ & $\begin{array}{c}\text { PERSEPSI } \\
\text { PROFESIONAL } \\
\text { DOSEN }\end{array}$ & $\begin{array}{l}\text { SARANA } \\
\text { BELANAR }\end{array}$ \\
\hline \multirow[t]{2}{*}{$N$} & Valid & 100 & 100 & 100 \\
\hline & Missing & 0 & 0 & 0 \\
\hline \multicolumn{2}{|c|}{ Mean } & 76.99 & 34.48 & 33.51 \\
\hline \multicolumn{2}{|c|}{ Median } & 80.00 & 36.00 & 34.00 \\
\hline \multicolumn{2}{|c|}{ Mode } & 80 & 36 & 36 \\
\hline \multicolumn{2}{|c|}{ Sted. Deviation } & 12.453 & 5.098 & 6.239 \\
\hline \multicolumn{2}{|c|}{ Variance } & 155.081 & 25.969 & 38.919 \\
\hline \multicolumn{2}{|c|}{ Range } & 55 & 35 & 35 \\
\hline \multicolumn{2}{|c|}{ Minimum } & 40 & 10 & 10 \\
\hline \multicolumn{2}{|c|}{ Maximum } & 95 & 45 & 45 \\
\hline
\end{tabular}

Tabel 4.5

Hasil Pengujian Normalitas Data dengan Bantuan Program SPSS

Tests of Normality

\begin{tabular}{|l|r|r|r|r|r|r|}
\hline & \multicolumn{3}{|c|}{ Kolmogorov-Smirnov } & \multicolumn{3}{c|}{ Shapiro-Wilk } \\
\cline { 2 - 7 } & Statistic & \multicolumn{1}{c|}{$\mathrm{df}$} & \multicolumn{1}{c|}{ Siq. } & Statistic & \multicolumn{1}{c|}{$\mathrm{df}$} & \multicolumn{1}{c|}{ Sig. } \\
\hline PRESTASI BELAJAR & .225 & 100 & .000 & .892 & 100 & .000 \\
PERSEPSI & .147 & 100 & .000 & .917 & 100 & .000 \\
PROFESIONAL DOSEN & .114 & 100 & .003 & .958 & 100 & .003 \\
SARANA BELAJAR &
\end{tabular}

a. Lilliefors Significance Correction 
Tabel 4.5 di atas dapat diketahui bahwa nilai statistik pada kolom Kolmogorov-Smirnov untuk variabel prestasi belajar (Y) sebesar 0.225 , persepsi profesionalisme dosen $\left(\mathrm{X}_{1}\right)$ sebesar 0.147 dan nilai untuk variabel sarana belajar $\left(\mathrm{X}_{2}\right)$ sebesar 0.114 . Jika dibandingkan dengan kriteria pengujian, ketiga variabel tersebut memenuhi kriteria atau berdistribusi normal karena memiliki nilai statistic $>0,05$.

Tabel 4.6

Uji Linearitas regresi prestasi belajar Bahasa Indonesia (Y) atas profesionalisme dosen (X1)

ANOVA Table

\begin{tabular}{|c|c|c|c|c|c|c|c|}
\hline & & & $\begin{array}{l}\text { Sum of } \\
\text { Squares }\end{array}$ & df & Mean Square & $F$ & sig. \\
\hline \multirow{5}{*}{$\begin{array}{l}\text { PRESTASIBELAJAR* } \\
\text { PERSEPSI } \\
\text { PROFESIONALLOSEN }\end{array}$} & \multirow[t]{3}{*}{ Between Groups } & (Combined) & 6662.921 & 20 & 333.146 & 3.029 & .000 \\
\hline & & Linearity & 4091.920 & 1 & 4091.920 & 37.199 & 000 \\
\hline & & Deviation from Linearity & 2571.001 & 19 & 135.316 & 1.230 & .256 \\
\hline & \multicolumn{2}{|l|}{ Within Groups } & 8690.069 & 79 & 110.001 & & \\
\hline & \multicolumn{2}{|l|}{ Total } & 15352.990 & 99 & & & \\
\hline
\end{tabular}

Dari tabel 4.6 di atas, diketahui besarnya nilai sig pada baris Deviation from Linearity 0,256 yang berarti lebih besar dari 0,05, karena nilai sig >0,05, bentuk persamaan regresi prestasi belajar bahasa Indonesia atas sarana belajar adalah linear.
Dari tabel 4.6 di atas, diketahui besarnya nilai sig pada baris Deviation from Linearity 0,256 yang berarti lebih besar dari 0,05, karena nilai sig $>0,05$, bentuk persamaan regresi prestasi belajar bahasa Indonesia atas sarana belajar adalah linear.

Tabel 4.7.

Uji linearitas regresi prestasi belajar Bahasa Indonesia (Y) atas sarana belajar (X1)

ANOVA Table

\begin{tabular}{|c|c|c|c|c|c|c|c|}
\hline & & & $\begin{array}{l}\text { Sum of } \\
\text { Squares }\end{array}$ & $d f$ & Mean Square & $\mathrm{F}$ & Sig. \\
\hline \multirow{5}{*}{$\begin{array}{l}\text { PRESTASI BELAJJAR * } \\
\text { SARANA BELAJAR }\end{array}$} & \multirow[t]{3}{*}{ Between Groups } & (Combined) & 7091.256 & 25 & 283.650 & 2.541 & .001 \\
\hline & & Linearity & 3295.779 & 1 & 3295.779 & 29.520 & .000 \\
\hline & & Deviation from Linearity & 3795.477 & 24 & 158.145 & 1.416 & .130 \\
\hline & \multicolumn{2}{|l|}{ Within Groups } & 8261.734 & 74 & 111.645 & & \\
\hline & \multicolumn{2}{|l|}{ Total } & 15352.990 & 99 & & & \\
\hline
\end{tabular}

Dari tabel 4.7 di atas dapat diketahui besarnya nilai sig pada baris Deviation from Linearity 0,130 yang berarti lebih besar dari 0,05. Karena nilai sig > 0,05, maka dapat disimpulkan bahwa bentuk regresi prestasi belajar bahasa Indonesia atas sarana belajar adalah linier.
Dari tabel 4.7 di atas dapat diketahui besarnya nilai sig pada baris Deviation from Linearity 0,130 yang berarti lebih besar dari 0,05. Karena nilai sig > 0,05, maka dapat disimpulkan bahwa bentuk regresi prestasi belajar bahasa Indonesia atas sarana belajar adalah linier. 
Tabel 4.8

Pengujian Homogenitas Kelompok Data $\mathrm{X}_{1}-\mathrm{Y}$

\section{Test of Homogeneity of Variances}

PRESTASL BELAJAR
\begin{tabular}{|r|r|r|c|}
\hline $\begin{array}{c}\text { Levene } \\
\text { Statistic }\end{array}$ & $\mathrm{df1}$ & $\mathrm{df} 2$ & Siq. \\
\hline 1.109 & 15 & 79 & .363 \\
\hline
\end{tabular}

Tabel 4.9

Pengujian Homogenitas Kelompok Data $\mathrm{X}_{2}-\mathrm{Y}$

\section{Test of Homogeneity of Variances}

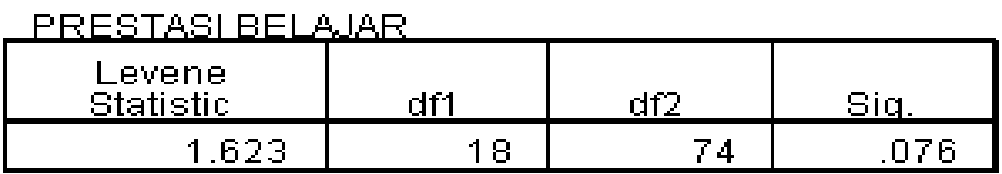

Hasil perhitungan dengan SPSS untuk kelompok data $\mathrm{X}_{1}-\mathrm{Y}$ diperoleh sign, $=0,363$, dan untuk kelompok data $\mathrm{X}_{2}-\mathrm{Y}$ diperoleh sign $=0,076$. Karena sign> 0,05, maka Ho diterima sehingga varians kedua populasi (kelompok data $\mathrm{X}_{1}-\mathrm{Y}$ dan kelompok data $\mathrm{X}_{2}-\mathrm{Y}$ ) identik (tidak berbeda secara signifikan).

Tabel 4.10

ANOVA ${ }^{b}$

\begin{tabular}{|ll|r|r|r|r|r|}
\hline \multicolumn{1}{|c|}{} & \multicolumn{1}{c|}{$\begin{array}{c}\text { Sum of } \\
\text { Madel }\end{array}$} & & df & Mean Square & \multicolumn{1}{c|}{ F } & Sig. \\
\hline 1 & Regression & 4315.861 & 2 & 2157.931 & 18.965 & $.000^{=}$ \\
& Residual & 11037.129 & 97 & 113.785 & & \\
& Total & 15352.990 & 99 & & & \\
\hline
\end{tabular}

a. Predictors: (Constant), SARANA BELAJAR, PERSEPSI PROFESIONAL DOSEN

b. Dependent Variable: PRESTASI BELAJAR

Tabel 4.11

ANOVA ${ }^{\text {b }}$

\begin{tabular}{|ll|r|r|r|r|r|}
\hline \multicolumn{1}{|c|}{} & \multicolumn{1}{c|}{$\begin{array}{c}\text { Sum of } \\
\text { Squares }\end{array}$} & df & Mean Square & \multicolumn{1}{c|}{ F } & Sig. \\
\hline 1 & Regression & 4315.861 & 2 & 2157.931 & 18.965 & $.000=$ \\
& Residual & 11037.129 & 97 & 113.785 & & \\
& Total & 15352.990 & 99 & & & \\
\hline
\end{tabular}

a. Predictors: (Constant), SARANA BELAJAR, PERSEPSI PROFESIONAL DOSEN

b. Dependent Variable: PRESTASI BELAJAR

Tabel 4.12

Coefficients ${ }^{3}$

\begin{tabular}{|c|c|c|c|c|c|c|}
\hline \multirow[b]{2}{*}{ Made } & & \multicolumn{2}{|c|}{ Unstandardized Coefficients } & \multirow{2}{*}{$\begin{array}{c}\begin{array}{c}\text { Standardized } \\
\text { Coefficients }\end{array} \\
\text { Beta }\end{array}$} & \multirow[b]{2}{*}{$\mathrm{t}$} & \multirow[b]{2}{*}{ Sig. } \\
\hline & & $\underline{B}$ & Std. Error & & & \\
\hline \multirow[t]{3}{*}{1} & (Constant) & 32.677 & 7.355 & & 4.443 & .000 \\
\hline & $\begin{array}{l}\text { PERSEPSI } \\
\text { PROFESIONAL DOSEN }\end{array}$ & .937 & .313 & .383 & 2.994 & .003 \\
\hline & SARANA BELAJAR & .359 & .256 & .180 & 1.403 & .164 \\
\hline
\end{tabular}

a. Dependent Variable: PRESTASI BELAJAR 
1. Pengaruh Persepsi atas Profesionalisme Dosen $\left(\mathrm{X}_{1}\right)$ dan Sarana Belajar $\left(\mathrm{X}_{2}\right)$ secara Bersama-sama terhadap Prestasi Belajar Mahasiswa dalam Mata Kuliah Bahasa Indonesia (Y) Berdasarkan hasil penghitungan pada Tabel 4.11 dan persamaan regresi ganda, hipotesis statistik pertama, Ho: Tidak terdapat pengaruh variabel persepsi atas profesionalisme dosen (X1) dan variabel sarana belajar (X2) secara bersama-sama terhadap variabel prestasi belajar mahasiswa dalam mata kuliah bahasa Indonesia (Y) ditolak karena nilai $F_{\text {hitung }}=18,965>$ $\mathrm{F}_{\text {tabel }}=3,12$ dan nilai sig $=0,000<$ 0,05 . F tabel dihitung berdasarkan taraf nyata $5 \%$ dengan derajat pembilang $(\mathrm{k})=2$ (banyaknya variabel bebas), dan derajat penyebut dk $(n-k-1)=97$. Artinya hipotesis penelitian yang menyatakan bahwa terdapat pengaruh persepsi atas profesionalisme dosen dan sarana belajar secara bersama-sama terhadap prestasi mahasiswa dalam mata kuliah bahasa Indonesia dapat diterima. Pengaruh ini sangat signifikan karena mempunyai angka nilai sig $<0,000$.

Selanjutnya, berdasarkan tabel 4.12 diperoleh persamaan regresi ganda dengan fungsi $\hat{\mathrm{Y}}=32,677$ $0,937 \mathrm{X}_{1}+0,359 \mathrm{X}_{2}$ yang berarti dapat digunakan untuk membuat simpulan mengenai pengaruh persepsi atas profesionalisme dosen $\left(\mathrm{X}_{1}\right)$ dan sarana belajar $\left(\mathrm{X}_{2}\right)$ terhadap Prestasi mahasiswa dalam mata kuliah bahasa Indonesia (Y)

Kekuatan hubungan antara persepsi atas profesionalisme dosen $\left(\mathrm{X}_{1}\right)$ dan sarana belajar $\left(\mathrm{X}_{2}\right)$ secara bersama-sama terhadap Prestasi Mahasiswa dalam mata kuliah Bahasa Indonesia (Y) ditunjukkan oleh $\mathrm{R}_{\mathrm{y} 12}=0,530$ pada tabel 4.10. Lebih lanjut, berdasarkan tabel 4.10 dapat dilihat koefisien determinasi $\mathrm{R}_{\mathrm{y} .12}^{2}=0,281$. Artinya, $28,1 \%$ variansi Prestasi mahasiswa dalam mata kuliah Bahasa Indonesia (Y) dapat dijelaskan oleh persepsi atas profesionalisme dosen $\left(\mathrm{X}_{1}\right)$ dan sarana belajar $\left(\mathrm{X}_{2}\right)$ secara bersamasama. Dengan demikian, dari hasil pengujian tersebut, dapat dijelaskan bahwa semakin tinggi persepsi atas profesionalisme dosen $\left(\mathrm{X}_{1}\right)$ dan sarana belajar $\left(\mathrm{X}_{2}\right)$, secara bersamasama Prestasi mahasiswa dalam mata kuliah bahasa Indonesia akan semakin meningkat pula.

2. Pengaruh Persepsi atas Profesionalisme Dosen $\left(\mathrm{X}_{1}\right)$ terhadap Prestasi Belajar Mahasiswa dalam Mata Kuliah Bahasa Indonesia (Y)

$\begin{array}{lrr}\text { Tabel } & 4.12 \text { di atas dan } \\ \text { persamaan } & \text { regresi } & \text { ganda } \\ \text { menunjukkan } & \text { bahwa } & \text { hipotesis }\end{array}$
statistik adalah (Ho): Tidak terdapat pengaruh variabel persepsi atas profesionalisme dosen (X1) terhadap variabel prestasi belajar mahasiswa mata kuliah Bahasa Indonesia (Y) ditolak karena nilai t hitung untuk persepsi profesionalisme dosen (X1) sebesar 2,994 sedangkan $t$ tabel sebesar 1,66, jadi nilai t hitung lebih besar dari t tabel atau 2, 994>1,66 dengan signifikansi $=0,000$. Hal ini berarti hipotesis yang menyatakan bahwa terdapat pengaruh persepsi atas profesionalisme dosen terdapat prestasi belajar mahasiswa dalam mata kuliah bahasa Indonesia dapat diterima. Dengan demikian, Ho ditolak dan Ha diterima, maka keadaan ini menunjukkan bahwa terdapat pengaruh positif antara profesionalisme dosen (X1) dengan prestasi mahasiswa dalam mata kuliah Bahasa Indonesia (Y). 
3. Pengaruh Variabel Persepsi atas Sarana Belajar $\left(\mathrm{X}_{2}\right)$ terhadap Prestasi Mata Kuliah Bahasa Indonesia (Y)

Berdasarkan tabel 4.12 di atas dan persamaan regresi ganda, hipotesis statistik ketiga adalah Ho: Tidak terdapat pengaruh variabel persepsi sarana belajar (X2) terhadap prestasi mahasiswa dalam mata kuliah bahasa Indonesia (Y) diterima karena nilai t hitung untuk sarana belajar (X2) sebesar 1,403, sedangkan $\mathrm{t}$ tabel sebesar 1,66. Jadi nilai $\mathrm{t}$ hitung $<\mathrm{t}$ tabel atau $<1,66$, dengan tingkat signifikansi $=0,000$. Dengan demikian, keadaan ini menunjukkan bahwa tidak terdapat pengaruh positif sarana belajar (X2) terhadap prestasi mahasiswa dalam mata kuliah Bahasa Indonesia (Y). Oleh karena itu, hipotesis penelitian yang menyatakan terdapat pengaruh variabel persepsi sarana belajar terhadap variabel prestasi mahasiswa dalam mata kuliah Bahasa Indonesia (H1) ditolak.

Penelitian ini dilakukan untuk mengetahui pengaruh antara persepsi atas profesionalisme dosen $\left(\mathrm{X}_{1}\right)$ dan sarana belajar $\left(\mathrm{X}_{2}\right)$ terhadap prestasi mahasiswa dalam mata kuliah bahasa Indonesia (Y).

1. Pengaruh Persepsi atas

Profesionalisme Dosen dan Sarana

Belajar secara Bersama-sama terhadap Prestasi Mata Kuliah Bahasa Indonesia

Persamaan regresi telah memenuhi persyaratan yang diperlukan, antara lain variabel dependen mengikuti distribusi normal, dan hasil uji linearitas diperoleh persamaan regresi variabel dependen terhadap variabel independen adalah linear.

Hasil pengujian diperoleh nilai $F_{\text {hitung }}=18,965>F_{\text {tabel }}=3,12$ dan nilai sig $=0,000<0,05$. Hal ini menunjukkan variabel persepsi atas profesionalisme dosen dan variabel sarana belajar secara bersama-sama memiliki pengaruh yang signifikan terhadap prestasi belajar mahasiswa dalam mata kuliah bahasa Indonesia.

Selanjutnya, berdasarkan pengujian SPSS yang telah dilakukan mengenai analisis korelasi, diperoleh koefisien korelasi sebesar 0,530 dan koefisien determinasi sebesar 28,1\%. Hal ini menyatakan terbukti bahwa koefisien korelasi tersebut signifikan. Artinya, terdapat pengaruh variabel bebas $X_{1}$ (persepsi atas profesionalisme dosen) dan $\mathrm{X}_{2}$ (sarana belajar) secara bersamasama terhadap variabel terikat $\mathrm{Y}$ (Prestasi mahasiswa mata kuliah Bahasa Indonesia).

Selain itu, sesuai dengan analisis regresi diperoleh persamaan garis regresi $\hat{Y}=32,677+0,937 X_{1}$ $+0,359 X_{2}$. Nilai konstanta $=32,677$ yang menunjukkan bahwa mahasiswa dengan persepsi atas profesionalisme dosen dan sarana belajar paling rendah, sehingga meraih prestasi belajar yang kurang baik, sedangkan nilai koefisien regresi sebesar 0,937 dan 0,359 menunjukkan bahwa terdapat pengaruh positif variabel $\mathrm{X}_{1}$ (persepsi atas profesionalisme dosen) dan variabel $\mathrm{X}_{2}$ (sarana belajar) secara bersama-sama terhadap variabel terikat Y (Prestasi mahasiswa dalam mata kuliah bahasa Indonesia).

2. Pengaruh antara Persepsi atas Profesionalisme Dosen $\left(\mathrm{X}_{1}\right)$ terhadap Prestasi Mahasiswa dalam Mata Kuliah Bahasa Indonesia (Y)

Berdasarkan hasil pengujian diperoleh $\mathrm{t}_{\text {hitung }}=2,994>\mathrm{t}_{\text {tabel }}=1,66$, dapat dinyatakan terdapat pengaruh 
yang signifikan variabel profesionalisme dosen terhadap variabel prestasi belajar dalam mata kuliah Bahasa Indonesia.

Menurut hasil pengujian diperoleh dari deskripsi data setelah dilakukan analisis korelasi diperoleh koefisien korelasi sebesar 0,516 dan koefisien determinasi sebesar $26,7 \%$. Setelah dilakukan pengujian program SPSS, terbukti bahwa koefisien korelasi tersebut signifikan. Hal itu berarti bahwa terdapat pengaruh variabel bebas $\mathrm{X}_{1}$ (persepsi atas profesionalisme dosen) terhadap variabel terikat $\mathrm{Y}$ (prestasi mahasiswa dalam mata kuliah Bahasa Indonesia). Dari analisis regresi diperoleh persamaan garis regresi $\hat{\mathrm{Y}}=33,491+1,262 \mathrm{X}_{1}$. Nilai konstanta $=33,491$ menunjukkan bahwa mahasiswa dengan persepsi atas profesionalisme dosen paling rendah hanya mendapatkan Prestasi dalam mata kuliah Bahasa Indonesia di bawah 50 , sedangkan nilai koefisien regresi sebesar 1,262 menunjukkan bahwa terdapat pengaruh positif variabel $\mathrm{X}_{1}$ (persepsi atas profesionalisme dosen) terhadap variabel terikat $\mathrm{Y}$ (Prestasi mata kuliah bahasa Indonesia). Setelah dilakukan pengujian linieritas garis regresi dengan me program SPSS, diperoleh simpulan bahwa garis regresi tersebut linier.

Menurut sintesis teori yang terdapat di Bab II, persepsi atas profesionalisme dosen merupakan faktor eksternal yang dapat mempengaruhi Prestasi belajar mahasiswa. Prestasi atas profesionalisme dosen adalah persepsi mahasiswa terhadap profesionalisme dosen yang meliputi penguasaan materi pembelajaran, penguasaan dan penghayatan landasan kependidikan, penguasaan proses-proses kependidikan, keguruan dan pembelajaran, kemampuan sosial penyesuaian diri tuntutan kerja, kemampuan penyesuaian pada lingkungan, penampilan sikap sebagai dosen, penampilan diri pada keseluruhan situasi pendidikan, pemahaman nilai yang dianut sebagai dosen, penghayatan dan penampilan nilai yang dianut sebagai dosen, dan persepsi atas penampilan upaya diri dosen sebagai panutan dan teladan bagi mahasiswa. Dari informasi kuantitatif dan teori tersebut, peneliti berasumsi bahwa terdapat pengaruh positif dan signifikan persepsi atas profesionalisme dosen terhadap Prestasi Mahasiswa dalam mata kuliah Bahasa Indonesia.

3. Pengaruh Persepsi Sarana Belajar terhadap Prestasi Mahasiswa dalam Mata Kuliah Bahasa Indonesia

Berdasarkan hasil pengujian diperoleh $t_{\text {hitung }}=1,403>t_{\text {tabel }}=1,66$, dapat dinyatakan tidak terdapat pengaruh yang signifikan variabel sarana belajar terhadap variabel prestasi belajar mahasiswa dalam mata kuliah Bahasa Indonesia. Selain itu, setelah dilakukan analisis korelasi, diperoleh koefisien korelasi sebesar 0,463 dan koefisien determinasi sebesar $21,5 \%$. Terbukti bahwa koefisien korelasi tersebut tidak signifikan. Hal itu berarti bahwa tidak terdapat pengaruh yang signifikan variabel sarana belajar terhadap variabel prestasi mahasiswa mata kuliah bahasa Indonesia.

Dari analisis regresi diperoleh persamaan garis regresi $\hat{Y}=45,998+0,925 X_{2}$. Nilai konstanta $=45,998$ menunjukkan bahwa mahasiswa dengan sarana belajar paling rendah meraih 
prestasi belajar yang kurang baik, sedangkan nilai koefisien regresi sebesar 0,925 menunjukkan bahwa setiap kenaikan persepsi atas sarana belajar sebesar satu satuan, maka akan diikuti dengan kenaikan prestasi mahasiswa dalam mata kuliah bahasa Indonesia sebesar 0,925 . Setelah dilakukan pengujian linieritas garis regresi dengan menggunakan program SPSS, diperoleh simpulan bahwa garis regresi tersebut linier.

Berdasarkan hasil pengujian yang telah dinyatakan di atas, maka $t_{\text {hitung }}<t_{\text {tabel }}$, yang berarti $\mathrm{H}_{0}$ diterima atau hipotesis penelitian yang menyatakan terdapat pengaruh variabel persepsi sarana belajar terhadap variabel prestasi mahasiswa mata kuliah bahasa Indonesia $\left(\mathrm{H}_{1}\right)$ ditolak. Hal itu berarti bahwa tidak terdapat pengaruh persepsi atas sarana belajar $\left(\mathrm{X}_{2}\right)$ terhadap prestasi belajar mahasiswa dalam mata kuliah bahasa Indonesia (Y).

Menurut sintesis teori yang ada di BAB II, sarana belajar merupakan faktor eksternal yang dapat mempengaruhi prestasi belajar. Untuk dapat meningkatkan prestasi belajar mahasiswa yang maksimal, tentunya perlu diperhatikan berbagai faktor yang membangkitkan para mahasiswa untuk belajar dengan efektif. Hal tersebut dapat ditingkatkan apabila ada sarana penunjang, yaitu faktor sarana dan prasarana pendidikan dan dapat memanfaatkannya dengan tepat dan seoptimal mungkin. Dengan demikian, mahasiswa akan memiliki motivasi yang tinggi untuk belajar dengan sungguh-sungguh sehingga proses belajar mengajar dapat berjalan dengan lancar, teratur, efektif dan efisien dan dapat menghasilkan prestasi belajar yang sesuai dengan tujuan yang diharapkan. Dari informasi kuantitatif, peneliti berasumsi bahwa tidak terdapat pengaruh signifikan persepsi atas sarana belajar terhadap prestasi mahasiswa dalam mata kuliah bahasa Indonesia.

\section{SIMPULAN}

Penelitian ini bertujuan untuk mengetahui pengaruh persepsi atas profesionalisme dosen dan sarana belajar baik secara sendiri-sendiri maupun secara bersama-sama terhadap Prestasi mahasiswa dalam mata kuliah Bahasa Indonesia di ALTRI Jakarta. Setelah dilakukan analisis, diperoleh simpulan sebagai berikut.

1. Terdapat pengaruh yang signifikan persepsi atas profesionalisme dosen (X1) dan sarana belajar (X2) secara bersama-sama terhadap prestasi belajar mahasiswa dalam mata kuliah Bahasa Indonesia (Y). Hasil pengujian signifikansi diperoleh $\mathrm{F}_{\text {hitung }}=18,965>\mathrm{F}_{\text {tabel }}=3,12$ dan nilai sig $=0,000<0,05$. Persepsi profesionalisme dosen(X1) dan sarana belajar (X2) secara bersamasama menyumbang sebesar $28,1 \%$ terhadap variasi Prestasi belajar mahasiswa dalam mata kuliah Bahasa Indonesia(Y) melalui persamaan regresi ganda $\hat{Y}=32,677$ $+0,937 \mathrm{X}_{1}+0,359 \mathrm{X}_{2}$ yang signifikan pada taraf 0,05 .

2. Terdapat pengaruh signifikan persepsi profesionalisme dosen (X1) terhadap prestasi belajar mahasiswa dalam mata kuliah bahasa Indonesia (Y). Hasil pengujian signifikansi diperoleh $\mathrm{t}_{\text {hitung }}=2,994>\mathrm{t}_{\text {tabel }}=$ 1,66. Persepsi atas profesionalisme dosen (X1) menyumbang sebesar $26,7 \%$ terhadap variasi prestasi 
belajar mahasiswa dalam mata kuliah Bahasa Indonesia (Y).

3. Tidak terdapat pengaruh signifikan persepsi sarana belajar terhadap prestasi mahasiswa dalam mata kuliah Bahasa Indonesia (Y) karena berdasarkan hasil pengujian signifikansi diperoleh $t_{\text {hitung }}=1,403$ $<t_{\text {tabel }}=1,66$. Sarana belajar menyumbang sebesar 21,5\% terhadap variasi prestasi mahasiswa dalam mata kuliah Bahasa Indonesia (Y) .

Berdasarkan simpulan di atas, penulis menyarankan hal berikut. Dari hasil penelitian kontribusi yang diberikan kedua variabel bebas terhadap peningkatan prestasi belajar mahasiswa dalam mata kuliah Bahasa Indoensia yang paling rendah adalah variabel sarana belajar (hanya 21,5\%). Oleh karena itu, penulis menyarankan agar segera ada perbaikan atau menambah sarana belajar yang ada pada saat sekarang ini di ALTRI Jakarta, misalnya, laboratorium komputer yang mutakhir (up to date), fasilitas perpustakaan yang baik, dan alat pembelajaran. Dengan perbaikan sarana belajar itu, diharapkan mahasiswa dapat lebih termotivasi untuk meningkat prestasi belajarnya, khususnya dalam mata kuliah Bahasa Indonesia.

\section{DAFTAR PUSTAKA}

Arikunto, Suharsimi. 1986. DasarDasar Evaluasi Pendidikan. Jakarta: Bumi Aksara.

1987. Pengelolaan Materiil. Cetakan I. Jakarta: PT Prima Karya.

\section{Manajemen}

Pengajaran. Jakarta: PT Rineka Cipta.
1993. Organisasi dan Administrasi Pendidikan Teknologi dan Kejuruan. Cetakan II. Jakarta: PT Grafindo Persada.

1998. Prosedur Penelitian Suatu Pendekatan Praktek. Jakarta: Rineka Cipta.

Dalyono, M. 2001. Psikologi Pendidikan. Jakarta: PT Rineka Cipta. -2006.Administrasi

Pendidikan. Cetakan IV . Jakarta: PT Rineka Cipta.

Djamarah. 2000. Guru dan Anak Didik dalam Interaksi Edukatif. Jakarta: Rineka Cipta.

Hamalik, Oemar. 1990. Metode Belajar dan Kesulitan-Kesulitan Belajar. Bandung: Tarsito. --. 1991. Manajemen Belajar di Perguruan Tinggi (Pendekatan Sistem Kredit Semester). Bandung: SinarBaru. 1978.Perencanaan

Pengajaran Berdasarkan

Pendekatan Sistem. Jakarta: Bumi Aksara.

Ibrahim, Bafadal. 2003. Seri Manajemen Peningkatan Mutu Pendidikan Berbasis Perlengkapan Sekolah Teori dan Aplikasi. Cetakan I. Jakarta: PT BumiAksara.

Likert, Rinses. 1967. The Human Organization: It's Management and Value. New York: McGraw Hill.

Mulyasa, E. 2004.Manajemen Berbasis Sekolah. Cetakan VII. Bandung: PT Remaja Rosdakarya.

Nurdin, Syafruddin. 2002. Guru Profesional dan Implementasi 
Kurikulum. Jakarta: Ciputat Pers.

Paryati, Sudarman. 2004. Belajar Efektif di Perguruan Tinggi. Bandung: Simbiosa Rekatama Media.

Purwanto, M Ngalim. 2001.PrinsipPrinsip dan Teknik Evaluasi Pengajaran. Cetakan X. Bandung: PT Remaja Rosdakarya. 2000. Psikologi Pendidikan. Cetakan XIX. Bandung: Remaja Rosdakarya.

$\begin{array}{ll}\text { Evaluasi. } & \text { 2002.Teknik-Teknik } \\ \text { Karya. } & \end{array}$

Sardiman, Arief S. dkk. 2007. Media Pendidikan: Pengertian, Pengembangan, dan Pemanfaatannya. Edisi I. Jakarta: PT Raja Grafindo Persada.

$\begin{array}{lcr}\text { Motivasi } & \text { 2008. Interaksi dan } \\ \text { Mengajar. } & \text { Jakarta: } & \text { dan } \\ \text { Grafindo Persada. } & \text { Raja }\end{array}$

SekretariatJendral MPR RI. 2000. Undang-Undang Dasar Negara Republik Indonesia Tahun 1945. Jakarta.

Slameto. 2003.Belajar dan FaktorFaktor yang Mempengaruhinya. Cetakan IV. Jakarta: Rineka Cipta.

Soepartono. 2000.Sarana dan Prasarana Olahraga. Jakarta: Departemen Pendidikan Nasional.
Subari.1994.Supervisi

Pendidikan.Cetakan I. Jakarta: BumiAksara.

Subroto, B. Suryo. 1998.Administrasi Pendidikan di Sekolah. Cetakan II. Jakarta: Bina Aksara.

Sugiyono. 2002.Metodologi Penelitian Administrasi. Bandung: Alfabeta. -2003.Statistika Penelitian dan Aplikasinya. Bandung: Alfabeta.

Sukardi, DewaKetut. 1983. Organisasi Administrasi Bimbingan Konseling di Sekolah. Surabaya: Usaha Nasional.

Surya, M. 2003. Selekta Kependidikan. Jakarta: Universitas Terbuka.

Syah, Muhibbin. 2002. Psikologi Pendidikan dengan Pendekatan Baru. Bandung: PT Remaja Rosdakarya.

Tilar, H.A.R. 2004.Paradigma Baru Pendidikan Nasional. Jakarta: RinekaCipta.

Tim Penyusun Kamus Pusat Pembinaan dan Pengembangan Bahasa.1988. Kamus Besar Bahasa Indonesia.Cetakan I. Jakarta: Balai Pustaka.

Usman, Moh. Uzer. 2002. Menjadi Guru Profesional. Bandung: PT RemajaRosdakarya.

Winkel, W.S. 1997. Psikologi Pengajaran. Cetakan IV. Jakarta: Grasindo 